\title{
Kaposiform hemangioendothelioma: current knowledge and future perspectives
}

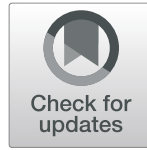

$\mathrm{Yi} \mathrm{Ji}^{\mathrm{i}^{* \dagger}} \mathbb{D}$, Siyuan Chen ${ }^{2 * \dagger}$, Kaiying Yang ${ }^{1}$, Chunchao Xia ${ }^{3}$ and $\mathrm{Li} \mathrm{Li}^{4}$

\begin{abstract}
Kaposiform hemangioendothelioma (KHE) is a rare vascular neoplasm with high morbidity and mortality. The initiating mechanism during the pathogenesis of KHE has yet to be discovered. The main pathological features of KHE are abnormal angiogenesis and lymphangiogenesis. KHEs are clinically heterogeneous and may develop into a lifethreatening thrombocytopenia and consumptive coagulopathy, known as the Kasabach-Merritt phenomenon (KMP). The heterogeneity and the highly frequent occurrence of disease-related comorbidities make the management of KHE challenging. Currently, there are no medications approved by the FDA for the treatment of KHE. Multiple treatment regimens have been used with varying success, and new clinical trials are in progress. In severe patients, multiple agents with variable adjuvant therapies are given in sequence or in combination. Recent studies have demonstrated a satisfactory efficacy of sirolimus, an inhibitor of mammalian target of rapamycin, in the treatment of KHE. Novel targeted treatments based on a better understanding of the pathogenesis of KHE are needed to maximize patient outcomes and quality of life. This review summarizes the epidemiology, etiology, pathophysiology, clinical features, diagnosis and treatments of KHE. Recent new concepts and future perspectives for KHE will also be discussed.

Keywords: Kaposiform hemangioendothelioma, Kasabach-Merritt phenomenon, Angiogenesis, Lymphangiogenesis, Treatment
\end{abstract}

\section{Introduction}

Kaposiform hemangioendothelioma (KHE) is a rare vascular neoplasm that is typically diagnosed in infancy or early childhood. KHE has intermediate tumor type with locally aggressive characteristics. The predominant feature of the pathology of KHE is progressive angiogenesis and lymphangiogenesis [1, 2]. Clinically, KHE has high morbidity rates, primarily due to local invasive features, compressive effects, or the life-threatening consumptive coagulopathy known as the Kasabach-Merritt phenomenon (KMP) [3-5]. Recent studies have rapidly expanded our basic knowledge of KHE, including the etiology, pathophysiology, diagnosis and treatment of the disorder. In this review, we describe the current knowledge and discuss future perspectives on KHE, with

\footnotetext{
* Correspondence: jijiyuanyuan@163.com; siy_chen@163.com

${ }^{\dagger}$ Yi Ji and Siyuan Chen contributed equally to this work.

${ }^{1}$ Division of Oncology, Department of Pediatric Surgery, West China Hospital of Sichuan University, Chengdu 610041, China

${ }^{2}$ Pediatric Intensive Care Unit, Department of Critical Care Medicine, West

China Hospital of Sichuan University, \#37 Guo-Xue-Xiang, Chengdu 610041,

China

Full list of author information is available at the end of the article
}

the aim of improving our understanding of KHE and preventing mortality and morbidity in severe cases.

\section{Definition}

Since 1940, the term 'Kasabach-Merritt syndrome (KMS)' has been used for patients with vascular anomalies that are associated with thrombocytopenia and coagulopathy [6]. KMS has also been widely considered a complication of 'hemangioma'. KHE was first designated by Zukerberg and coworkers in 1993 as an entity distinct from infantile hemangioma $(\mathrm{IH})$ because of its locally invasive growth, aggressive course and 'focal Kaposi-like appearance' [7]. In 1997, investigators from two different groups reported that the vascular lesions associated with KMS (or KMP) were not IHs as was previously believed $[8,9]$. Currently, KMP is defined as profound thrombocytopenia, together with consumptive coagulopathy and hypofibrinogenemia associated only with the vascular tumors, KHE and tufted angioma (TA) (Fig. 1) [10, 11]. Conceptually, KHE and TA are part of the same neoplastic spectrum and can be present in the same biopsy specimen of the same patient [12]. 


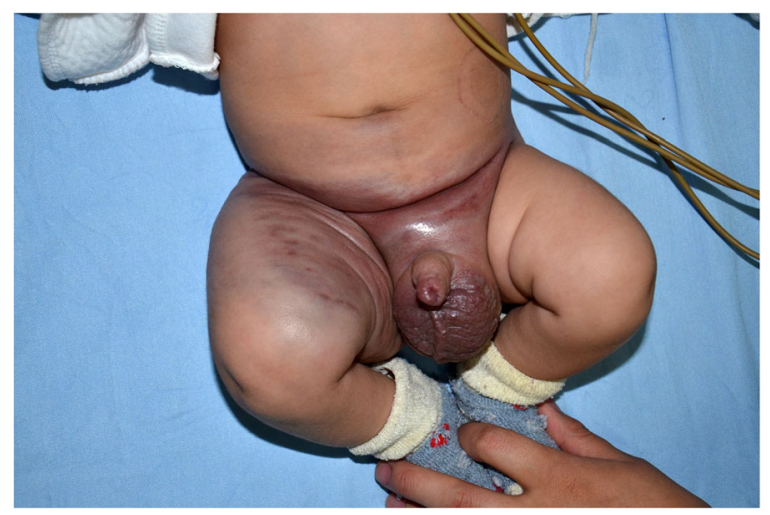

Fig. 1 A 3-month-old male infant presenting KHE associated with KMP. The tumor lesion grew progressively after the first week of age and extended through the whole thigh, scrotum and abdominal wall, with 'extensive thrombocytopenic purpura' as described by Kasabach and Merritt in 1940

\section{Epidemiology and demography}

Currently, there is a paucity of literature specifically addressing the incidence of KHE. In Massachusetts, the annual prevalence and incidence have been estimated at 0.91 and 0.071 per 100,000 children, respectively [13]. However, asymptomatic KHE lesions are less likely to be reported or diagnosed by pathology. Indeed, small asymptomatic or atypical KHEs can be misdiagnosed as unusual variants of $\mathrm{IH}$ or other vascular anomalies [14]. Therefore, the actual prevalence and incidence of KHE are most likely higher than those indicated in the limited published reports.

Previously, KHE was shown to have an equal sex predilection. However, a slight male predominance has been indicated by two large retrospective studies, both of which collected data from more than 100 patients with $\mathrm{KHE}[10,11]$. The distribution of age at onset has one peak within the first year of life when approximately 90\% of KHE are evident. Approximately 50\% of cutaneous lesions are visible or detectable at birth [14].

\section{Etiology}

In general, the etiology of KHE remains largely unknown. Almost all cases of KHE arise without any obvious cause. In rare scenarios, signs and symptoms of KHE/TA can worsen with trauma or infections. There is also evidence that aggravation or manipulation of the tumor either from surgery or trauma can incite KMP, whether the patient had a history of KMP or not [15-17]. In addition, rapid enlargement of the lesion with severe KMP development shortly after vaccination has been reported in several patients [18-21]. These phenomena raise the intriguing possibility that physical trauma and the inflammatory response might contribute to the aggravation of $\mathrm{KHE}$.
It is likely that the origin of KHE is multifactorial, with genetic factors being part of the contributing triggers, although the mutations in KHE tumor are sporadic rather than germline. Rapid advances in the area of molecular genetics have enabled the identification of somatic mutations in many types of vascular anomalies. Zhou and coworkers provided evidence of a somatic translocation between chromosomes 13 and 16 at the bands of $13 q 14$ and 16 p13.3 in $10 \%$ of metaphase cells in KHE lesions with the presence of normal cells in the karyotype [22]. Remarkably, the somatic activating GNA14 c.614A > T (p.Gln205Leu) mutation was found in 1/3 of KHE specimens and in 1/4 of TA specimens, although these studies were weakened by small sample size [23]. Somatic mutations in GNAQ and its paralogues (e.g., GNA11 and GNA14) have also been identified in many other vascular tumors [24, 25], vascular malformations [26, 27] and solid tumors $[28,29]$.

The GNAQ family encodes $G \alpha$ subunits that form a heterotrimer with $G \beta$ and $G \gamma$ subunits and bind Gprotein-coupled receptors (GPCRs). GPCRs are involved in many aspects of tumor and vascular biology [30, 31]. In addition, platelet aggregation, glucose secretion, and inflammation are among the physiological processes affected by GPCRs [32]. p.Gln205Leu substitution can induce changes in cellular morphology and render cells growth-factor independent by upregulating the MAPK/ ERK1/2 pathway (Fig. 2) [23]. However, it is important to note that although GNAQ mutations have been found in $\mathrm{KHE}$, we do not know whether they are causative or develop secondarily in the tumor.

It is unclear how mutations in the same gene can lead to different vascular anomalies or clinical manifestations, but the mechanism may be based on the location of the mutation in the gene, the cell type(s) affected, and/or the point in development at which the mutations occur [33]. In these scenarios, the highly variable clinical presentations of $\mathrm{KHE}$ further reflect the complexity of gene mutations in the development of this rare disease. It is also conceivable that undetected mutations exist in KHE lesions given that many technical hurdles are still present, although these are not likely to be insurmountable in the future.

\section{Pathophysiology}

The pathophysiology of KHE may not be attributable to a single mechanism, but rather, to a combination of events that have not yet been elucidated or understood completely.

\section{Angiogenesis and lymphangiogenesis}

$\mathrm{KHE}$ is the result of dysregulation of both angiogenesis and lymphangiogenesis. In vivo, mouse hemangioendothelioma cells can form KHE-like, intradermal tumors. Interestingly, overexpression of prospero-related homeobox-1 (Prox-1) in mouse hemangioendothelioma cells induces 


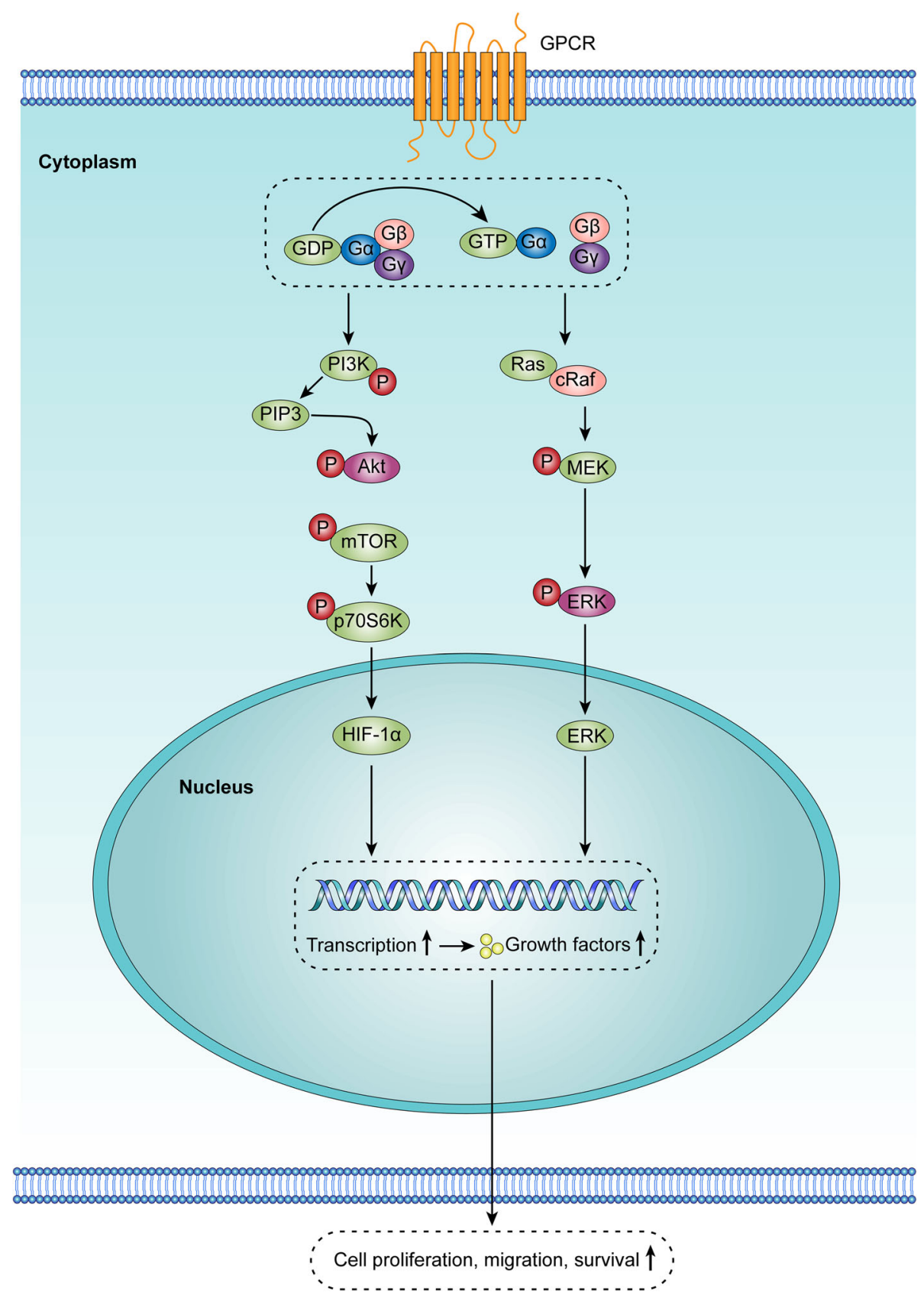

Fig. 2 G-protein-coupled receptors (GPCRs) participate in different physiological processes. The binding of ligands to GPCRs triggers a universal G protein allosteric mechanism that promotes the exchange of GDP with GTP on the a subunit of heterotrimeric G proteins. This event causes the dissociation of Ga from the dimer. Ga subunits mediate signals between GPCRs and intracellular signaling cascades. These signaling pathways include the PI3KJAKT/mTOR and MAPKJERK pathways, both of which can mediate different biological processes, such as cell proliferation, migration and survival. Mutations in GPCRs and G proteins have been found at a very high frequency in tumor cells and endothelial cells in vascular anomalies

an invasive phenotype in vivo, enhances the migration rate in vitro, and significantly upregulates the expression of podoplanin (D2-40) and vascular endothelial growth factor receptor-3 (VEGFR-3) [34]. Recent data indicated that KHE-derived mesenchymal stem cells (MSCs) have the capacity to support vascular network formation in vitro [35]. In addition to expressing VEGFR-3, KHE-derived
MSCs also show higher levels of VEGF-C than normal lymphatic endothelial cells [35].

\section{VEGF-C/VEGFR3 axis}

The vascular endothelial growth factor-C (VEGF-C)/ VEGFR3 axis in lymphatic endothelial cells (LECs) is important throughout lymphangiogenenic growth [36]. The 
expression of both VEGFR-3 and VEGF-C in KHE suggests that the VEGF-C/VEGFR3 axis may contribute to the aggressive behavior of KHE [37, 38]. The VEGF-C/ VEGFR3 axis has been implicated in tumor progression by directly affecting tumor cells or modulating lymphangiogenesis and the immune response (Fig. 3) [39]. The VEGF-C/VEGFR-3 axis has been demonstrated to promote tumor growth in an autocrine manner [40]. In addition to lymphangiogenesis, VEGF-C/VEGFR3 signaling has also been shown to be important for angiogenesis, acting together with VEGF-A/VEGFR-2 and Dll4/Notch signaling to control angiogenesis [41]. VEGF-C/VEGFR3 axis may play an important role in chronic inflammation associated with KHE [42, 43].

\section{Angiopoietin-2/tie-2 signaling}

The high serum levels of angiopoietin-2 (Ang-2) in patients with KHE raise the possibility that Ang- 2 might have a paracrine effect on endothelial cells (ECs) in KHE lesions. Remarkably, Ang-2 levels dramatically decrease with sirolimus treatment in patients with KHE and KMP [44]. It is therefore possible that Ang-2 might have a role in the

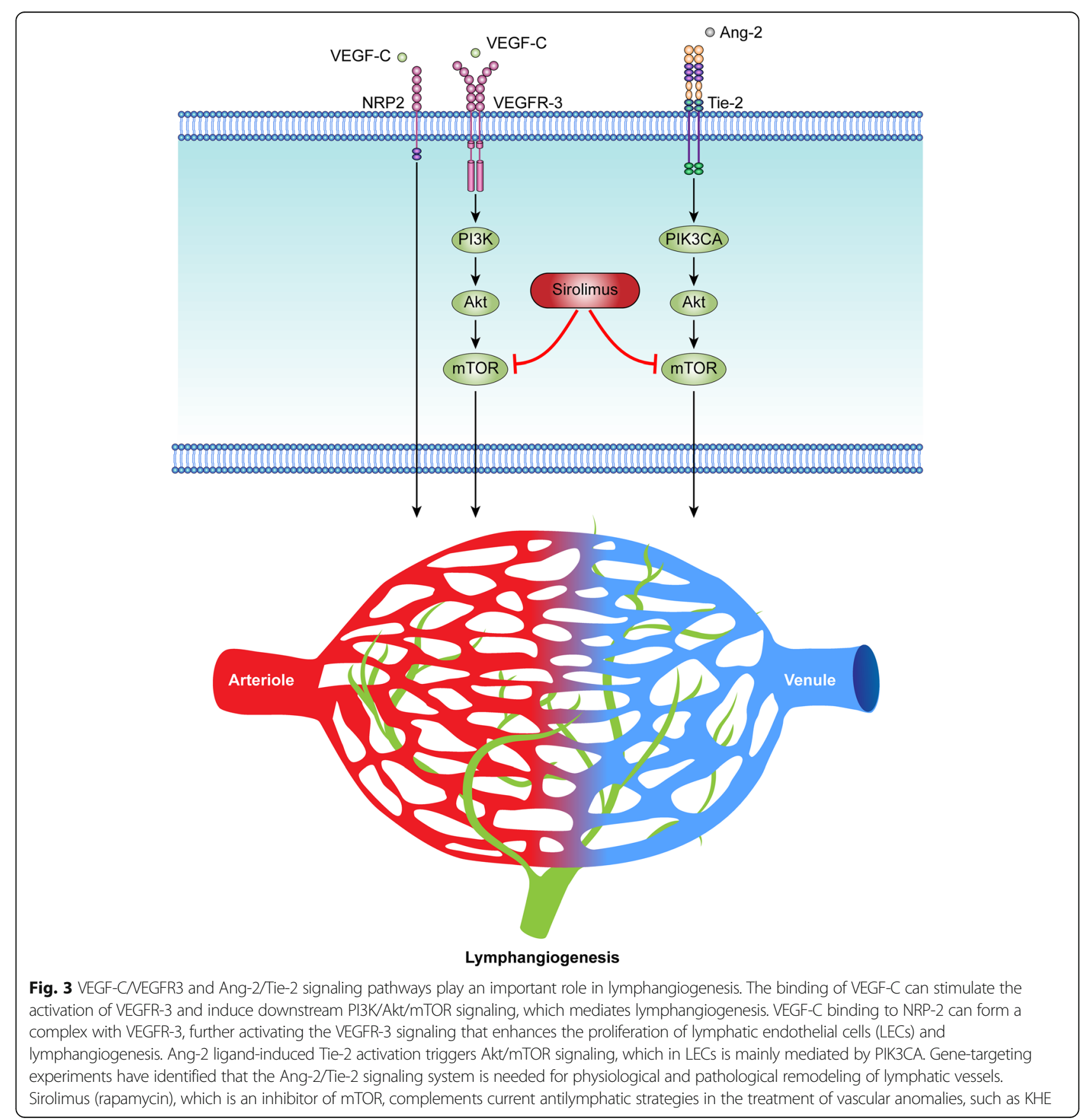


development of KMP in patients with KHE. The Ang/Tie2 ligand-receptor system is required for lymphatic and blood vessel development during midgestation. The Ang/Tie2 pathway controls vascular permeability, inflammation and pathological angiogenic and lymphatic responses postnatally. Ang-2 acts as a context-dependent weak Tie-2 agonist or antagonist that can inhibit the Ang-1/Tie-2 signaling axis [45]. In humans, Ang-2 levels are greatly increased during vascular remodeling, which occurs, for example, during vessel sprouting and inflammatory lymphangiogenesis [46]. This may be a potential explanation for the upregulation of Ang-2 in patients with KHE. Ang-2-induced Tie-2 activation triggers Akt/mTOR signaling, which in ECs is mainly mediated by PIK3CA (which encodes PI3K catalytic subunit- $\alpha$ ) [47].

\section{Platelet aggregation: a key trigger of KMP?}

Intralesional platelet trapping is followed by the activation and aggregation of platelets, which then results in activation of the coagulation cascade with subsequent consumption of clotting factors. Platelet trapping has been revealed histologically in KHE with or without KMP [48]. Of interest then is the mechanism or mechanisms of increased platelet trapping in KHE vessels. One hypothesis is that EC damage or alteration in KHE can lead to exposure of extracellular matrix components, which are ligands for platelet adhesion [1]. The C-type lectin-like receptor-2 (CLEC-2) expressed on platelets is an endogenous receptor of podoplanin, which in turn is widely expressed in ECs within the KHE lesions $[49,50]$. Binding of podoplanin to CLEC-2 can transmit platelet activation signals via Src family kinases, which may account for platelet aggregation in KHE [51].

Podoplanin is highly expressed in dysmorphic vessels within the lymphatic malformations, but no obvious platelet aggregation occurs in these lesions [52]. Therefore, there may also be alternative and/or additional mechanisms by which platelet trapping is triggered in KHE lesions [2, 53]. In $\mathrm{KHE}$, the thrombi in the microvasculature cause vessel occlusion and prevent normal blood flow, all of which can lead to elevated shear stress. It is recognized that high shear stress induces an increased activation of platelets in vitro and in vivo, with a mechanism dependent on von Willebrand factor interacting with both its platelet binding sites, glycoprotein (GP) Ib-IX and GP IIb-IIIa [54, 55]. With regard to KHE, platelets in circulating blood may become exposed to turbulent blood flow and high shear stress that results from the architecture of the small, convoluted and thrombus-obstructed vessels within the KHE lesions. This process in turn causes further platelet trapping and activation during the active phase of KHE.

Continued platelet aggregation, together with coagulopathy and hypofibrinogenemia with elevated D-dimer (coagulation markers), eventually result in intralesional hemorrhage, which clinically manifests as very purpuric, warm, painful, and rapidly enlarged tumor lesion [3]. In patients with KHE, the coexistence of KMP always represents aggressive tumor progression. Although the pathophysiological roles of activated platelets in the KHE tissue environment are not yet fully understood, these observations raise the intriguing possibility that the activated platelets might contribute to worsening coagulopathy by promoting critical processes such as neovascularization. This hypothesis is supported by findings that platelets are activated in different tumor vasculatures [56-59]. Platelets are reservoirs of proangiogenic proteins that are mainly stored in $\alpha$-granules and secreted upon physiological and pathological stimulations. Various types of tumor cells and tumor-derived ECs can activate platelets by different mechanisms. There is plenty of evidence that activated platelets exert their pleiotropic effects on many biological processes central to angiogenesis, progression, inflammation and metastasis in various tumor types [57, 60,61]. Improving our understanding of such platelet involvement in neovascularization may potentially help in the development of alternative treatment strategies for patients with KHE.

\section{Clinical characteristics}

The manifestations of KHE are variable and range from cutaneous lesions with wide varieties of appearances to deep masses without cutaneous signs. The clinical features also differ substantially between patients with KMP and patients without KMP [13, 14, 48]. In the majority of patients, KHE is a single soft tissue mass with cutaneous findings that range from an erythematous papule, plaque, or nodule to an indurated, purple and firm tumor. With KMP, these lesions are purpuric, hot to the touch, swollen and very painful. Most patients experience progressive lesion enlargement and/or symptom progression [62-64]. However, a small but significant minority of KHEs do not grow [13, 48]. Approximately $12 \%$ of patients lack cutaneous involvement [14].

\section{Complications}

Complications in patients with KHE are common. The complication severity strongly depends on the age, lesion size, lesion location, lesion extension into the deep tissue and vital organs, and associated hematologic abnormalities. It is prudent for clinicians to remain vigilant of potential complications and of risk factors that may herald future complications.

\section{Kasabach-Merritt phenomenon}

KMP occurs with an estimated incidence of 42 to $71 \%$ $[2,13,14,64]$. The thrombocytopenia is usually severe, with a median platelet count of $21 \times 10^{9} / \mathrm{L}$ at the initial presentation of KMP [14]. KHE lesions with KMP have progressive engorgement and purpura. KMP can lead to significant pain and secondary bleeding. As far as we know, KHE appear to be congenital as the majority of 
cases are diagnosed in the newborn/infancy period. It is now thought that the few cases in which adults were found to have KHE or to develop KMP, occurred because of an inciting event like trauma or pregnancy. The risk of KMP is highest for congenital KHEs with a large size (especially $>8 \mathrm{~cm}$ in diameter) $[48,65]$. Anatomic location may also be a predictor of KMP. Clinically, intrathoracic KHEs are frequently associated with KMP [66-68]. The frequency of KMP in the retroperitoneal KHEs was also high $[13,14]$. Evidently, intrathoracic and retroperitoneal lesions tend to be more expansive and infiltrative and are more likely to develop KMP. The identification of the most dangerous factors associated with KMP will be enormously helpful to treating clinicians.

\section{Musculoskeletal disorders}

The infiltrative nature and destructive growth patterns of KHE can cause functional limitations and pain; all of these musculoskeletal disorders may affect patients' abilities to perform routine daily activities and eventually influence quality of life $[4,69]$. Acute pain at the tumor sites is a common symptom during KMP [14]. Even in patients without KMP, musculoskeletal disorders are frequently seen in cases involving the extremities, with a majority of these lesions located on or adjacent to joints [70]. Progressive thoracolumbar scoliosis can be seen in patients with thoracic or retroperitoneal lesions [71-73]. It is important that these patients are diagnosed early and treated more aggressively at the outset even in the absence of KMP. In some cases, residual KHEs will continue to infiltrate surrounding tissues, erode bone and destroy joints. Infiltration of the muscles and connective tissues in patients with KHE can alter the structural matrix and mechanical properties of these tissues, leading to chronic degenerative changes. Pathologically, untreated KHE lesions are characterized by progressive fibrosis [12]. There is ample evidence for the crucial role of platelet activation and aggregation in the development of fibrosis in different tissues and organs [74, 75]. It is conceivable that platelet activation and aggregation in muscles and connective tissues during KHE infiltration can activate variable fibrotic pathways. The diffuse intraarticular and periarticular fibrosis can further aggravate muscular atrophy and lead to subluxations and flexion contracture of the involved joints. Patients may eventually suffer from recalcitrant pain and fixed contractures (Fig. 4).

\section{Lymphedema}

Lymphedema is the chronic, progressive swelling of subcutaneous tissue caused by inadequate lymphatic function. Lymphedema may be caused by anomalous development (primary) or injury (e.g., infection) to lymph nodes or lymphatic vessels [76]. Lymphedema may be a potential sequela of KHE, particularly tumor involving the legs $[12,77]$.
KHE involving the proximal extremity, particularly at or adjacent to the inguinal or axillary lymph nodes, may influence lymphatic development or damage the lymphatic vasculatures. In this scenario, it is hypothesized that the mechanical obstruction of the lymphatic flow during the acute phase of KMP may eventually lead to lymphedema [78]. In addition, active and chronic inflammation may also play a role in the development of lymphedema in patients with KHE.

\section{Compression of vital structures}

Compression of vital structures may occur in a number of settings and is far more frequently observed in patients with KMP than in patients without KMP [14]. The progressive expansion of the mass during the active phase of KMP can further compromise the vital structures. Obstructing KHEs of the airway typically involves the neck and thorax $[67,79]$. KHEs involving the pancreas are extremely uncommon but have the potential to cause obstructive jaundice [80, 81]. If compression of vital structures is visualized, prompt therapy should be initiated even without KMP.

\section{Diagnosis}

The diagnosis of KHE often requires an analysis of clinical, imaging, hematological and/or histological characteristics, but even with all of these data, the diagnosis might not be readily apparent in certain cases [73]. In patients with deep KHE without KMP (bone and/or joint and so on), a definitive diagnosis is often delayed because of the non-specific and wide variety of symptoms.

Ultrasound is the modality of choice for small and superficial lesions [82]. Magnetic resonance imaging (MRI) is generally first-line assessment because the deep infiltrating nature of KHE may not be apparent on physical exam or on ultrasound. MRI with and without gadolinium has the most value in the diagnosis of KHE as well as for clearly determining the extent of involvement and response to treatment [83]. On MRI scans, KHEs usually exhibit ill-defined margins and are characterized by multiplanar involvement, diffuse enhancement, and adjacent fat stranding in unusual locations, iso-intensity relative to adjacent muscle on T1weighted imaging, hyperintensity on T2-weighted imaging (Fig. 5). Adjacent bone and/or joint changes are common. The MRI findings of these changes include destruction of the adjacent cortex, injury of the epiphyseal region and invasion to near joints. Deep KHE with KMP should be considered in patients presenting with an unexplained severe thrombocytopenia and coagulopathy, especially in patients coexisting with cutaneous purpura and severe anemia. MRI scan of the abdomen and chest should be recommended for such patients $[84,85]$.

Biopsy is gold standard for diagnosis and should be performed if possible and safe. Biopsy is frequently not 


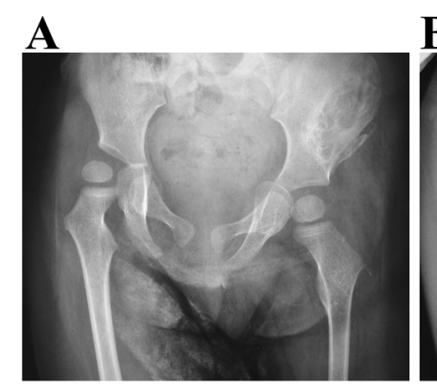

D

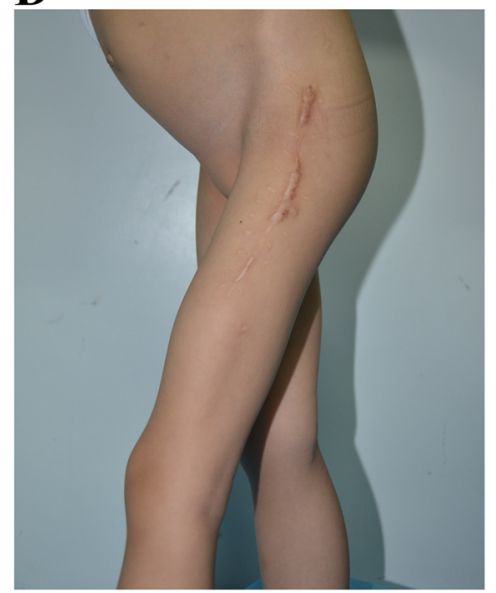

B

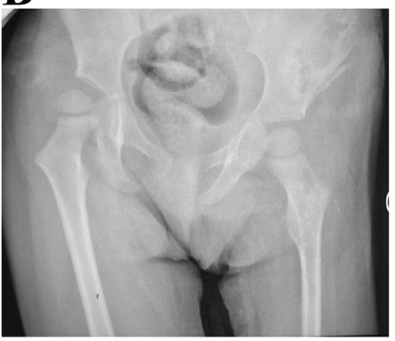

E
C
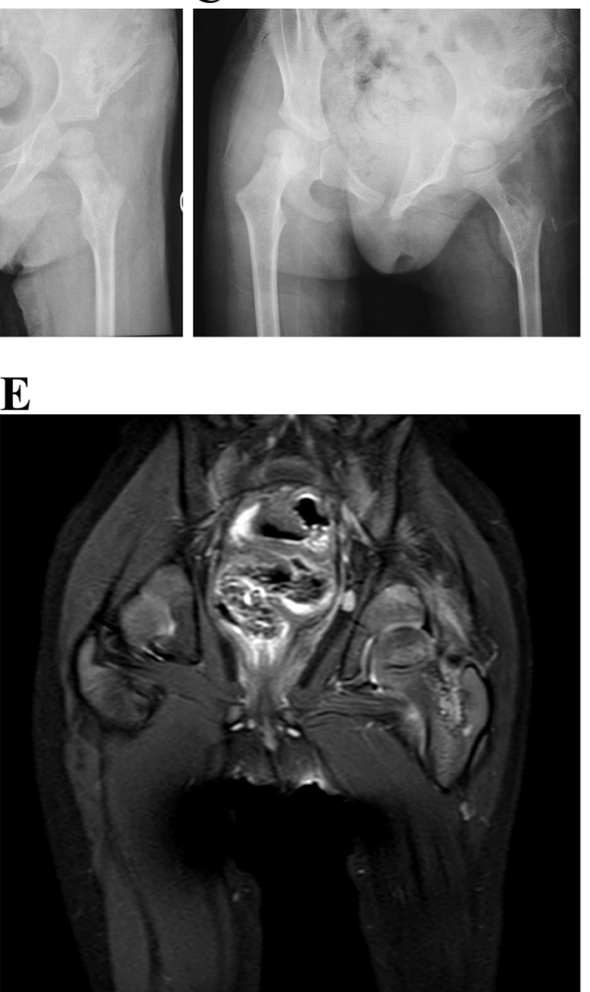

Fig. 4 Deep KHE with bone and joint destruction in a 3.5-year-old girl. The patient had been diagnosed with a left-hip KHE associated with KMP at 1 year of age. She received a partial resection at the local hospital. Although surgical excision improved the associated KMP, she exhibited a progressively decreased hip range of motion. An anteroposterior pelvis radiograph showed right hip subluxation and progressive bone erosion in the left ilium and proximal femur before referral ( $\mathbf{a}, \mathbf{b}$ and $\mathbf{c}$ ). Coronal T2-weighted MRI revealed a deep lesion infiltrating the left ilium and proximal femur at the time of referral to our department $(\mathbf{d}, \mathbf{e})$

possible or recommended in KHE with severe KMP, and can potentially worsen the coagulopathy. Biopsy specimens should be considered in patients with an uncertain diagnosis and atypical clinical manifestation (e.g., at an unusual site). The histologic hallmark of KHE is infiltrating, defined, rounded and confluent nodules, which are composed of spindle endothelial cells. These spindle endothelial cells align to form malformed lymphatic channels and slit-like vascular lumina containing erythrocytes, along with platelet thrombi, eosinophilic hyaline bodies and the extravasation of hemosiderin deposits. Immunohistochemical staining shows that endothelial cells in KHE lesions are positive both for vascular endothelial markers CD31 and CD34, lymphatic endothelial marker VEGFR-3, D2-40, lymphatic endothelial hyaluronan receptor-1 and Prox-1, but negative for glucose transporter-1(Glut-1) and human herpes virus-8 staining (Fig. 6) [2, 8, 9].

\section{Differential diagnoses}

The heterogeneous clinical, radiographic and laboratory findings of KHE raise an extensive differential diagnosis that includes $\mathrm{IH}$, venous malformation, congenital hemangioma and Kaposiform lymphangiomatosis (KLA), among others. A definitive preoperative differential diagnosis between deep KHE and a malignant tumor (e.g., metastasis neuroblastoma and sarcoma) is also challenging in patients with spine involvement without KMP.

\section{Infantile hemangioma}

One of the most important diseases to rule out in the differential diagnosis of $\mathrm{KHE}$ is $\mathrm{IH}$. The appearance of $\mathrm{IH}$ is dictated by the depth, location, and stage of evolution. A defining feature of $\mathrm{IH}$ is its dramatic growth (between 5.5 and 7.5 weeks of age) and development into a disorganized mass of blood vessels [86]. Cutaneous IHs are usually diagnosed clinically and frequently without needing for imaging. Imaging examinations and other investigations may be required in special situations (e.g., paraglottic or hepatic IHs). Both KHE and IH will look hypervascular on ultrasound. MRI is helpful in differentiating the difficult cases. Throughout the development of IHs, ECs in IH lesions are positive for Glut-1, which is absent in $\mathrm{KHE}$ and other vascular tumors [87, 88]. 

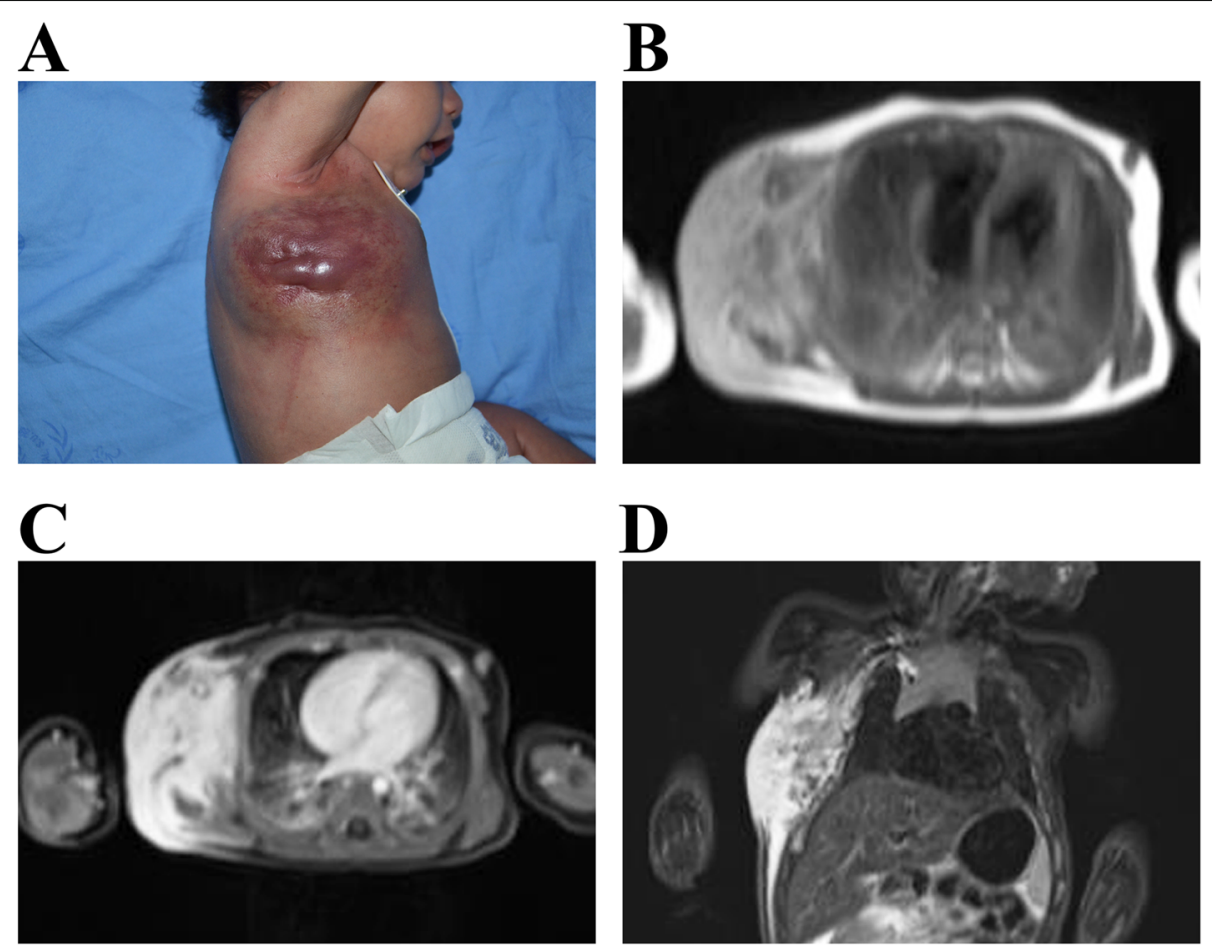

Fig. 5 Clinical and MRI features of KHE with KMP. a A 2-month-old boy was found to have a chest wall mass after birth. The mass became progressively indurated and purpuric. The boy developed profound thrombocytopenia and consumptive coagulopathy. b Horizontal T1-weighted MRI revealed that the heterogeneous mass was isointense relative to the adjacent muscle on T1-weighted imaging. Horizontal (c) and sagittal (d) T2-weighted MRI revealed hyperintense lesions infiltrating the right lateral chest wall

\section{Congenital hemangiomas}

Congenital hemangiomas are biologically and behaviorally distinct from KHEs. They are benign vascular tumors of infancy that arise in utero and are present and fully formed at birth. The 3 variants of congenital hemangiomas are rapidly involuting congenital hemangiomas (RICHs), partially involuting congenital hemangiomas (PICHs) and noninvoluting congenital hemangiomas (NICHs) $[89,90]$. The defining feature of RICHs is accelerated regression, which is usually complete within the first year of life, leaving behind atrophic skin (Fig. 7). NICHs persist in a stable state without growth or involution. However, a slight enlargement of NICHs over the years has recently been reported [91]. PICHs evolve from RICHs to persistent NICH-like lesions. Congenital hemangiomas can look very much like KHE particularly in the newborn period. Congenital hemangiomas do not exhibit progressive postnatal growth. In contrast, KHE tumors that develop KMP will appear to 'grow' and become engorged and purpuric in the first days/weeks/months of life. Mild consumption of coagulation factors can occur but most importantly, the coagulopathy associated with congenital hemangioma is not associated with bleeding issues and tends to self resolve in 1 to 2 weeks [92]. Treatment with surgical excision, as there are no medical therapies currently, for congenital hemangiomas may be required for cosmetic reasons or to resolve persistent pain in patients with $\mathrm{NICH}$ [89].

\section{Venous malformation}

KHE with KMP should be differentiated from the clotting disorder associated with extensive venous malformations (VMs). VMs are slow-flow vascular malformations present at birth. In patients with extensive VMs, especially involving the trunk and/or extremities, localized intravascular coagulopathy can occur at baseline and be worsening by any aggravation of the malformation such as trauma or surgery. The levels of fibrinogen are low, associated with elevated D-dimer and fibrin degradation products. However, the thrombocytopenia is less profound in VMs than in KHE with KMP [93]. VMs can usually be diagnosed based on patient history, physical examination and MRI. On light microscopy, VMs are characterized by enlarged and irregular venous channels lined by a flattened layer of ECs [94].

\section{Kaposiform lymphangiomatosis}

KLA is a rare, complex lymphatic disorder with multifocal or diffuse lesions. KLAs often involve the mediastinum, lung, abdomen and multiple bones [95-97]. Interestingly, thrombocytopenia and coagulopathy in KLA have overlapping features with KMP in KHE. The thrombocytopenia in 


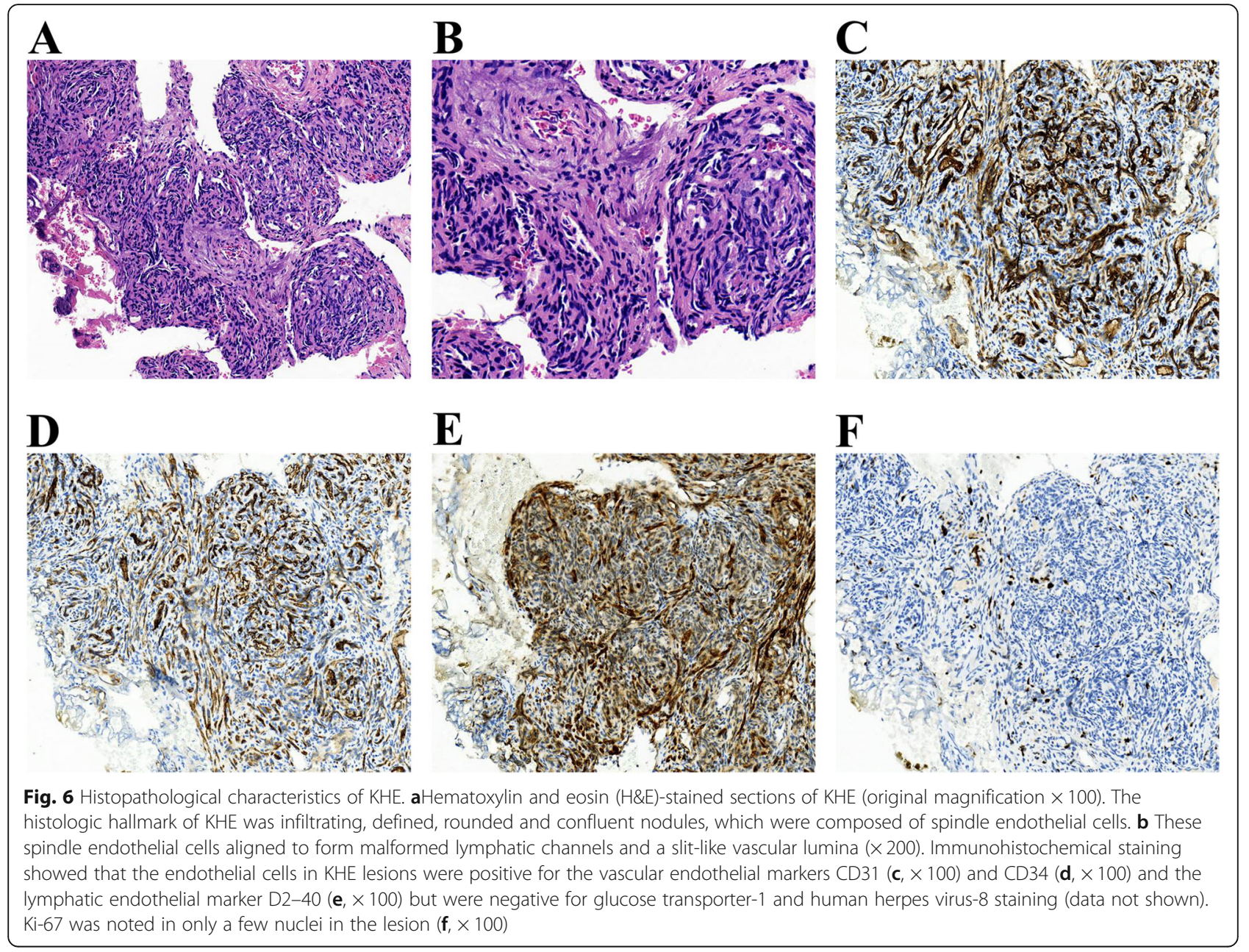

some KLAs is extremely severe, similar to that observed in KMP [98, 99]. Histologically, KLAs are composed of malformed lymphatic channels with dispersed and poorly marginated clusters or sheets of spindled lymphatic ECs [96, 98]. In vitro, KHE cells can support vascular network formation, whereas KLA cells appear inert in this capacity
[35]. A somatic activating NRAS variant (c.182 A > G, p. Q61R) was recently identified in patients with KLA but was absent in KHE samples, thus providing a molecular means to further differentiate these two entities [100]. In addition, KLA appears to be more refractory to medical therapies, with an overall survival rate of only $34 \%$ [96].

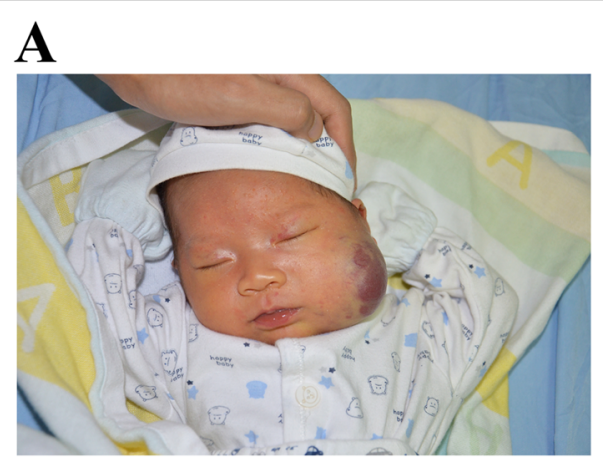

B

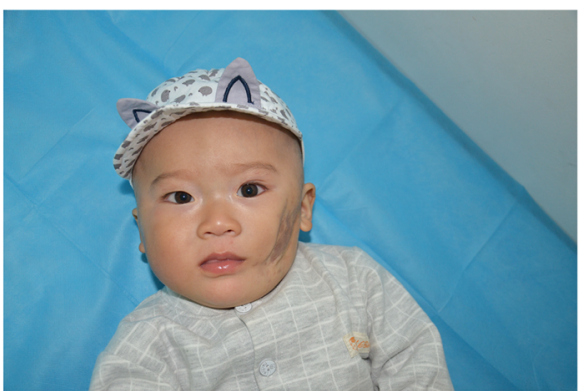

Fig. 7 Rapidly involuting congenital hemangiomas (RICH). a RICH is fully formed at birth and then involutes, mostly during the first year of life. The patient's hematologic parameters were within the normal reference ranges. b The same RICH involuted rapidly without any treatment. By 9 months of age, the lesion had involuted completely, leaving dermal atrophy 


\section{Management}

Due to the marked heterogeneity and rarity of KHEs, no validated scores have been established to assess disease severity. Consensus treatment statements by Drolet et al. [83] were published in 2013. Medical treatments with corticosteroids and/or vincristine have been recommended for the management of KHE. However, these recommendations are based on expert opinion rather than rigorous clinical studies. There is a lack of well-designed clinical trials and insufficient evidence to support existing interventions. There is also no definite treatment guideline for the long-term observation of patients with KHE [101].

Currently, the management of KHE has been based upon a review of the available evidence, expert opinions, and clinical experiences. Sirolimus has recently been suggested as a treatment option for complicated vascular anomalies and tumors in children, including KHE with or without KMP [102]. In many patients, multiple treatments are given in sequence or in combination. Notably, the treatment practices and regimens for KHE should be tailored to individual patients and guided by specific clinical circumstances. Patients with KMP should be treated aggressively with a combined regimen; monotherapy is usually not recommended. Several studies for combined regimens in the treatment of KHE are currently accruing subjects, including one randomized controlled trial (ClinicalTrials.gov identifier NCT03188068). Supportive care treatments (e.g., cryoprecipitate) are often required for patients with KMP (Table 1). Platelet transfusion should not be used unless the patient is actively bleeding or in preparation for surgery. Ideally, a patient with KHE who also exhibits severe complications or is at risk of complications should be referred to a multidisciplinary team for evaluation and treatment.

Table 1 Management options for $\mathrm{KHE}^{\mathrm{a}}$

\begin{tabular}{|c|c|c|}
\hline Specific approach & Dosage & Comment \\
\hline \multicolumn{3}{|l|}{ Systemic } \\
\hline Corticosteroids & $\begin{array}{l}\text { Oral prednisolone } 2 \mathrm{mg} / \mathrm{kg} / \mathrm{d} \text { or intravenous } \\
\text { methylprednisolone } 1.6 \mathrm{mg} / \mathrm{kg} / \mathrm{d}\end{array}$ & $\begin{array}{l}\text { Corticosteroid plus vincristine or corticosteroid } \\
\text { plus sirolimus is recommended as the first-line } \\
\text { therapy for severe KMP. Corticosteroids should } \\
\text { be tapered as soon as medically feasible. }\end{array}$ \\
\hline Vincristine & Intravenous 0.05 mg/kg once weekly & $\begin{array}{l}\text { Vincristine plus aspirin and/or ticlopidine and } \\
\text { vincristine plus corticosteroid are } \\
\text { recommended for severe KMP. }\end{array}$ \\
\hline Sirolimus & $\begin{array}{l}\text { Oral } 0.8 \mathrm{mg} / \mathrm{m}^{2} / \text { dose twice daily, adjust for a } \\
\text { trough level of } 8-15 \mathrm{mg} / \mathrm{ml}\end{array}$ & $\begin{array}{l}\text { Sirolimus plus corticosteroid is now } \\
\text { recommended as the first-line therapy for } \\
\text { severe KMP. Lower serum levels }(2-5 \mathrm{mg} / \mathrm{ml}) \\
\text { of sirolimus are recommended for long-term } \\
\text { use or toxicities. }\end{array}$ \\
\hline Ticlopidine & Oral $10 \mathrm{mg} / \mathrm{kg} / \mathrm{d}$ & Monotherapy is not recommended for KMP. \\
\hline Interferon-a & Subcutaneous injection, $1-3 \times 10^{6} \mathrm{U} / \mathrm{m}^{2}$ & $\begin{array}{l}\text { Interferon-a is not recommended for patients } \\
\text { younger than } 1 \text { year old due to its significant } \\
\text { neurologic toxicities. }\end{array}$ \\
\hline Propranolol & Oral $2-3 \mathrm{mg} / \mathrm{kg} / \mathrm{d}$ & Monotherapy is not recommended for KMP. \\
\hline \multicolumn{3}{|l|}{ Topical } \\
\hline Sirolimus gel & $0.1 \%$, twice daily & Used for superficial KHE. \\
\hline Tacrolimus ointment & $0.1 \%$, twice daily & Used for superficial KHE. \\
\hline \multicolumn{3}{|l|}{ Supportive care treatments } \\
\hline Fresh frozen plasma or cryoprecipitate & $\begin{array}{l}\text { The dosage used is based on the actual } \\
\text { situation of the patient (e.g., the severity of } \\
\text { hypofibrinogenemia). }\end{array}$ & $\begin{array}{l}\text { Used for active bleeding, platelet count } \\
<30 \times 10^{9} / \mathrm{L} \text {, and/or fibrinogen }<1.0 \mathrm{~g} / \mathrm{L} \text {. }\end{array}$ \\
\hline Platelets & $\begin{array}{l}\text { The dosage used is based on the actual } \\
\text { situation of the patient (e.g., the severity of } \\
\text { thrombocytopenia). }\end{array}$ & $\begin{array}{l}\text { Platelet transfusion is only recommended for } \\
\text { active bleeding or before a surgical procedure } \\
\text { when the platelet count is less than } 30 \times 10^{9} / \mathrm{L} \text {. }\end{array}$ \\
\hline Packed red blood cells & $\begin{array}{l}\text { The dosage used is based on the actual } \\
\text { situation of the patient (e.g., the severity } \\
\text { of anemia). }\end{array}$ & $\begin{array}{l}\text { Transfusion of packed red blood cells is } \\
\text { recommended for patients who have } \\
\text { symptomatic anemia (hemoglobin } \\
\text { concentration less than } 80 \mathrm{~g} / \mathrm{L} \text { ). }\end{array}$ \\
\hline Active nonintervention & $\begin{array}{l}\text { Adjust scheduled visits on the basis of } \\
\text { growth of the tumor and/or the } \\
\text { development of complications. }\end{array}$ & $\begin{array}{l}\text { Careful observation is recommended for } \\
\text { unchanged and uncomplicated KHE. }\end{array}$ \\
\hline
\end{tabular}




\section{Pharmacological treatments Vincristine}

Haisley-Royster et al. [103] reported encouraging findings regarding the successful use of vincristine in the management of KMP. Many studies have also demonstrated the satisfactory outcomes of vincristine in treating KHE with KMP, including steroid-resistant patients [5, 104-106]. First-line therapy with vincristine or vincristine plus corticosteroids is recommended for cases of KHE with KMP in consensus-derived guidelines [83, 107]. First-line treatment with vincristine has an overall response rate of $72 \%$ [108]. There is mounting evidence that vincristine monotherapy is not effective in very severe patients $[109,110]$. In this regard, successful use of vincristine plus ticlopidine has been reported in some cases $[5,111]$.

\section{Corticosteroids}

Systemic corticosteroid treatment is recommended as another first-line therapy for KMP because of its success in rapidly normalizing platelet counts [83, 107]. The sustained response, however, is variable, and many cases do not improve with corticosteroid monotherapy (with an overall response rate of 10-27\%), even when higher doses are given $[106,112]$. In addition, long-term corticosteroid use has undesired side effects, such as temporary growth retardation, an increased risk of infection and behavioral changes [113]. Recent studies have suggested that corticosteroids can be used in combination therapies for KMP $[73,114]$. Considering the undesirable side effects of longterm daily corticosteroid treatment in children, they should be weaned off these drugs as soon as medically feasible.

\section{Sirolimus}

Since 2010, an increasing number of studies have reported the exceptional effectiveness of sirolimus and everolimus, which are well-known mTOR inhibitors, on KHE. The authors described a reduction in KHE size, an eventual normalization of platelet counts in KMP patients, and in some cases, improvements in musculoskeletal pain, function and quality of life $[80,109,112,114-124]$. For patients who either did not respond to the previous treatment (e.g., corticosteroids and vincristine) or who relapsed once the dose was tapered, sirolimus therapy still exhibited a high response rate (94\%) [108]. However, sirolimus alone is usually not sufficient to treat severe KMP. In patients with severe KMP, sirolimus in combination with the short-term administration of corticosteroid has been recommended (Fig. 8) [114]. Sirolimus plus steroids is now considered as a first-line therapy for the treatment of KHE with KMP (versus vincristine plus steroids). Many clinicians (and families) prefer sirolimus (plus steroids) over vincristine because vincristine requires a central line.
Although sirolimus is clearly efficacious, rare side effects, such as interstitial pneumonitis and Pneumocystis carinii pneumonia, may be life-threatening [125, 126]. Currently, the optimal sirolimus dose and prophylactic regimen in patients with KHE has not been established. Many authors have reported maintaining the serum levels between 8 and $15 \mathrm{ng} / \mathrm{ml}[114,116,120]$. However, low-dose sirolimus (2-3 ng/ml serum levels) may be associated with low toxicity and has been demonstrated to be effective for treating patients without KMP [127]. Interestingly, there is mounting evidence that low-dose sirolimus markedly ameliorates the development of inflammation and fibrogenesis in animal models, providing a theoretical basis for its use in KHE with musculoskeletal disorders [128, 129].

\section{Topical treatments}

Several case reports and case series have reported success using topical sirolimus and tacrolimus ointment in superficial KHE/TA. The investigators have shown a good response of KHE/TA to twice daily topical application of these drugs $[130,131]$. Tacrolimus is an anti-T-cell immunosuppressive drug that is FDA-approved as a topical gel formulation (available in a concentration of 0.03 and $0.1 \%)$ for the treatment of cutaneous inflammatory/fibrotic diseases [132]. The clinically important implication of topical treatments is that superficial KHE/TA can be treated with local/topical agents, thus decreasing the potential complications associated with systemic treatments. However, it is important to note that most of these cases are TA lesions rather than KHE. It is also important to ensure that there is not a deep component.

\section{Other pharmacological therapies}

Several other medicines have been used in an attempt to optimize efficacy. Ticlopidine and aspirin are specific antplatelet-aggregating agents. Successful use of ticlopidine plus aspirin in KMP has been described [133]. Interferon$\alpha$ and propranolol have also been used to treat KHE. However, the standard protocols are inadequate because responses to these agents are variable and unpredictable [134-137]. In addition, the side effects of interferon- $\alpha$ are significant and include spastic diplegia [138].

\section{Invasive interventions}

Elective resection of a KHE during the active phase of KMP is unusually not necessary and is ill advised. Given the young age of the patients and the vascularity of the tumors, these patients are at higher risk of blood loss and iatrogenic injury, along with worsening of the coagulopathy. Clinically, surgery is rarely an option for extensive KHEs or for patients in whom surgery will result in significant functional impairment. Conversely, surgery can be an approach for tumors in which a complete and 

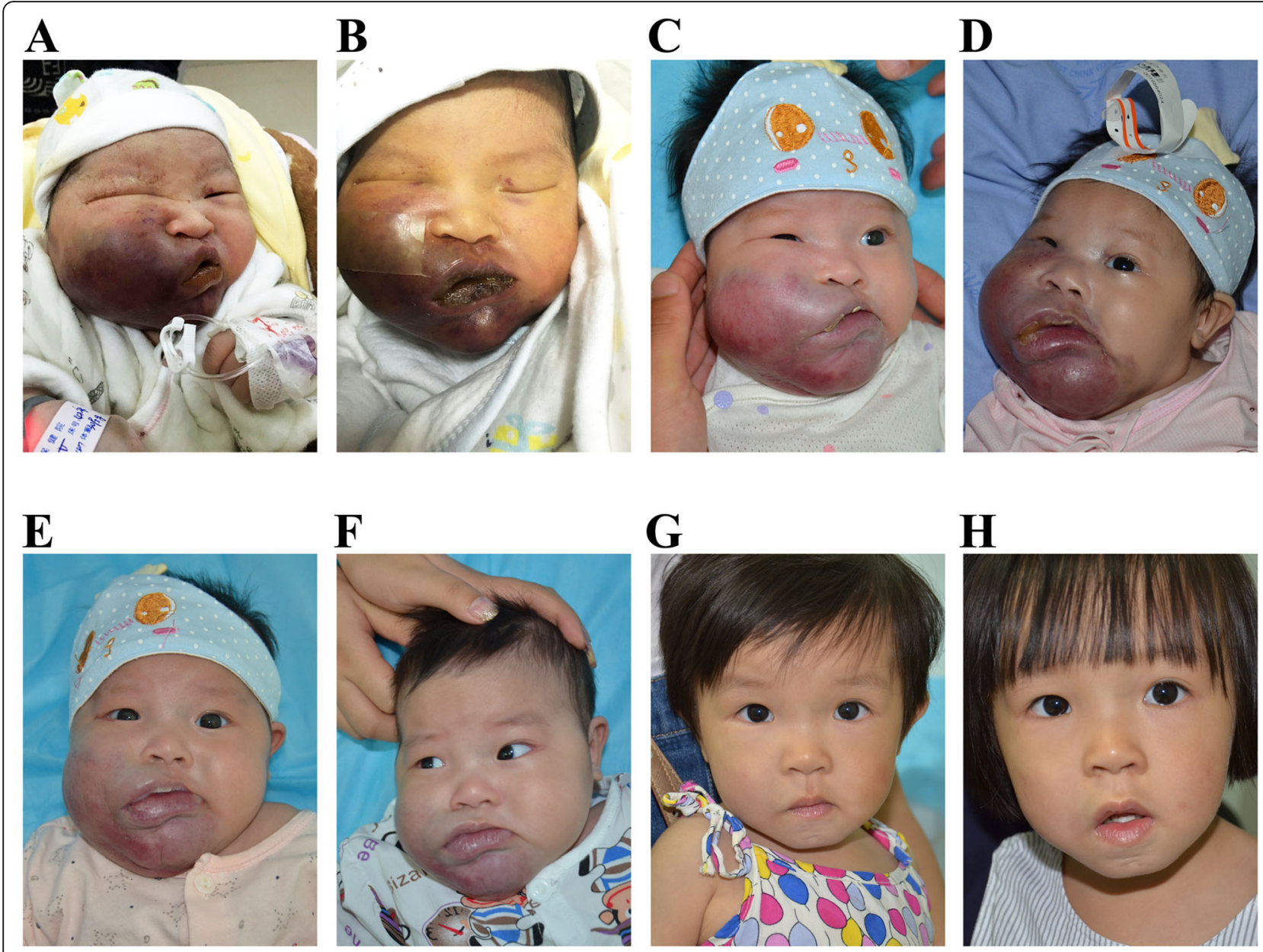

Fig. 8 Congenital KHE associated with KMP on the right face. Congenital KHEs with KMP likely represent a period of temporary and partial remission shortly after birth. The signs and symptoms may alleviate spontaneously. However, rebound growth of the lesions accompanying severe KMP would reoccur within the next several days or weeks. a The parents' photograph revealed a bluish, swollen and firm vascular mass on the right face after birth ( 2 days of age). Her platelet count was $7 \times 10^{9} / \mathrm{L}$. Without any special treatment, the tumor became soft and was stagnant in size. Her platelet count reached a highest value of $161 \times 10^{9} / \mathrm{L}$ (b: 1 week of age, c: 6.5 weeks of age). Subsequently, however, the tumor became progressively enlarged and displayed obvious ecchymosis (d: 8 weeks of age). The patient's platelet count dropped to $3 \times 10^{9} / \mathrm{L}$. She was treated with a combination therapy of sirolimus $\left(0.8 \mathrm{mg} / \mathrm{m}^{2}\right.$ administered twice daily) and prednisolone $(2 \mathrm{mg} / \mathrm{kg} / \mathrm{d})$. One $(\mathbf{e})$ and 4 weeks ( $\mathbf{f}$ ) after treatment. Within 10 days of combination therapy, the girl's platelet level normalized. The prednisolone was tapered and discontinued within the following 4 weeks, and sirolimus was continued. G, Twelve months after treatment. H, Photograph at 26 months of age (24 months of treatment) demonstrates a nearly complete involution of the lesion. Sirolimus was then tapered and discontinued

safe resection can be performed [48]. Surgery is also an option for resection of a fibrofatty residuum or reconstruction of damaged structures [12]. Failure of pharmacotherapy may lower the threshold for the resection of a cosmetically or functionally problematic KHE [139]. In patients with KMP, arterial embolization may have a role in disease control [139]. Embolization can initially decrease blood flow from the tumor and decrease risk of high output cardiac failure. However, a remarkable limitation of embolization is the technical difficulty of cannulating very small feeder vessels in young patients. The possibility of worsening the hematological parameters by invasive interventions is also important and highlights the need for employing more established techniques in these patients.

\section{Conclusions and future directions}

Although the incidence of KHE is low, it can cause morbidity and mortality in children and adults. Consequently, prompt diagnosis and appropriate management are crucial to improving the long-term prognosis of patients. Mutations and their pathways are providing potential targets for the development of novel pharmacotherapy for KHE. The future challenge will be to dissect the mutations and signaling cascades in terms of their pharmacological relevance. It is likely that the rapid advances in basic science and translational medicine will facilitate the development of important, new, and targeted molecular treatment strategies for KHE. Further clinical studies are also needed to refine the guidelines for the standard use of therapies and follow-up in patients with KHE. 


\section{Abbreviations}

Ang-2: Angiopoietin-2; CLEC-2: C-type lectin-like receptor-2; CT: Computed tomography; GP: Glycoprotein; GPCR: G-protein-coupled receptor; IH: Infantile hemngioma; KHE: Kaposiform hemangioendothelioma; KLA: Kaposiform lymphangiomatosis; KMP: Kasabach-Merritt phenomenon; KMS: Kasabach-Merritt syndrome; MRI: Magnetic resonance imaging; MSC: Mesenchymal stem cell; NRP-2: Neuropilin-2; Prox-1: Prospero-related homeobox-1; TA: Tufted angioma; VEGF-C: Vascular endothelial growth factor-C; VEGFR-3: Vascular endothelial growth factor receptor-3; VM: Venous malformations

\section{Acknowledgements}

We thank the patients and their parents for their co-operation and support, and for providing consent for publication.

\section{Authors' contributions}

YJ and SYC drafted the manuscript. YJ, SYC, KYY, CCX and LL were involved in the clinical management of these patients and collected clinical details of this study. All authors read and approved the final manuscript.

\section{Funding}

This work was supported by grants from the National Natural Science Foundation of China (Grants Nos. 81400862 and 81401606), the Key Project in the Science \& Technology Program of Sichuan Province (Grant No. 2019YFS0322), the Science Foundation for The Excellent Youth Scholars of Sichuan University (Grant No. 2015SU04A15), and the 1.3.5 Project for Disciplines of Excellence-Clinical Research Incubation Project of West China Hospital of Sichuan University (2019HXFH056).

\section{Availability of data and materials}

The datasets used and/or analyzed during the current study available from the corresponding author on reasonable request.

\section{Ethics approval and consent to participate}

The study was approved by the Ethics Committee of the West China Hospital of Sichuan University. Written informed consent was obtained from the patients' parents, according to the provisions of the Declaration of Helsinki.

\section{Consent for publication}

Written informed consent for publication this study was obtained from the patients' parents. Copies of the signed informed consent forms are available for review by the Series Editor of Journal of Hematology \& Oncology.

\section{Competing interests}

The authors declare that they have no competing interests, either financial or non-financial, that could be perceived as prejudicing the impartiality of the research reported.

\section{Author details}

'Division of Oncology, Department of Pediatric Surgery, West China Hospital of Sichuan University, Chengdu 610041, China. ${ }^{2}$ Pediatric Intensive Care Unit, Department of Critical Care Medicine, West China Hospital of Sichuan University, \#37 Guo-Xue-Xiang, Chengdu 610041, China. ${ }^{3}$ Department of Radiology, West China Hospital of Sichuan University, Chengdu 610041 China. ${ }^{4}$ Laboratory of Pathology, West China Hospital of Sichuan University, Chengdu 610041, China.

Received: 16 October 2019 Accepted: 28 January 2020

Published online: 03 February 2020

\section{References}

1. O'Rafferty C, O'Regan GM, Irvine AD, Smith OP. Recent advances in the pathobiology and management of Kasabach-Merritt phenomenon. Brit J Haematol. 2015;171(1):38-51.

2. Lyons LL, North PE, Mac-Moune LF, Stoler MH, Folpe AL, Weiss SW. Kaposiform hemangioendothelioma: a study of 33 cases emphasizing its pathologic, immunophenotypic, and biologic uniqueness from juvenile hemangioma. Am J Surg Pathol. 2004;28(5):559-68.

3. Mulliken JB, Anupindi S, Ezekowitz RAB, Mihm MC. Case 13-2004. New Engl J Med. 2004;350(17):1764-75.
4. Schaefer BA, Wang D, Merrow AC, Dickie BH, Adams DM. Long-term outcome for kaposiform hemangioendothelioma: a report of two cases. Pediatr Blood Cancer. 2017;64(2):284-6.

5. Fernandez-Pineda I, Lopez-Gutierrez JC, Chocarro G, Bernabeu-Wittel J, Ramirez-Villar GL. Long-term outcome of vincristine-aspirin-ticlopidine (VAT) therapy for vascular tumors associated with kasabach-Merritt phenomenon. Pediatr Blood Cancer. 2013;60(9):1478-81.

6. Kasabach H, Merritt K. Capillary hemangioma with extensive purpurareport of a case. Am J Dis Child. 1940;5(59):1093-70.

7. Zukerberg LR, Nickoloff BJ, Weiss SW. Kaposiform hemangioendothelioma of infancy and childhood. An aggressive neoplasm associated with Kasabach-Merritt syndrome and lymphangiomatosis. Am J Surg Pathol. 1993;17(4):321-8.

8. Enjolras O, Wassef M, Mazoyer E, Frieden IJ, Rieu PN, Drouet L, et al. Infants with Kasabach-Merritt syndrome do not have "true" hemangiomas. J Pediatr. 1997;130(4):631-40.

9. Sarkar M, Mulliken JB, Kozakewich HP, Robertson RL, Burrows PE. Thrombocytopenic coagulopathy (Kasabach-Merritt phenomenon) is associated with Kaposiform hemangioendothelioma and not with common infantile hemangioma. Plast Reconstr Surg. 1997;100(6):1377-86.

10. Adams DM, Brandão LR, Peterman CM, Gupta A, Patel M, Fishman S, et al. Vascular anomaly cases for the pediatric hematologist oncologists-An interdisciplinary review. Pediatr Blood Cancer. 2018;65(1):e26716 -n/a.

11. Mahajan P, Margolin J, lacobas I. Kasabach-Merritt Phenomenon: Classic Presentation and Management Options. Clin Med Insights Blood Disord. 2017;10:1179545X17699849.

12. Enjolras O, Mulliken JB, Wassef M, Frieden IJ, Rieu PN, Burrows PE, et al. Residual lesions after Kasabach-Merritt phenomenon in 41 patients. J Am Acad Dermatol. 2000;42(2 Pt 1):225-35.

13. Croteau SE, Liang MG, Kozakewich HP, Alomari Al, Fishman SJ, Mulliken JB, et al. Kaposiform hemangioendothelioma: atypical features and risks of Kasabach-Merritt phenomenon in 107 referrals. J Pediatr. 2013;162(1):142-7.

14. Ji Y, Yang K, Peng S, Chen S, Xiang B, Xu Z, et al. Kaposiform haemangioendothelioma: clinical features, complications and risk factors for Kasabach-Merritt phenomenon. Br J Dermatol. 2018;179(2):457-63.

15. Karnes JC, Lee BT, Phung T, Alomari Al, Mulliken JB, Greene AK. Adult-onset kaposiform hemangioendothelioma in a posttraumatic site. Ann Plast Surg. 2009:62(4):456-8.

16. Goyal A, Babu SN, Kim V, Katariya S, Rao KL. Hemangioendothelioma of liver and spleen: trauma-induced consumptive coagulopathy. J Pediatr Surg. 2002:37(10):E29.

17. Kim CY, Nam YH, Kim GD, Oh CW. Tufted angioma in site of healed herpes zoster: isotopic response. Clin Exp Dermatol. 2006;31(5):714-5.

18. Zeng YP, Ma DL. Tufted angioma arising at a site of BCG vaccination. Eur J Dermatol. 2013:23(1):102-3.

19. Choi JW, Na Jl, Hong JS, Kwon SH, Byun SY, Cho KH, et al. Intractable tufted Angioma associated with Kasabach-Merritt syndrome. Ann Dermatol. 2013; 25(1):129

20. Yue X, Zhao X, Dai Y, Shu Q. Episode of Kasabach-Merritt phenomenon following Japanese encephalitis vaccination: case report. Vaccine. 2017; 35(48):6594-7.

21. Ji Y, Chen S, Yang K, Xia C, Peng S. Development of Kasabach-Merritt phenomenon following vaccination: more than a coincidence? J Dermatol. 2018;45(10):1203-6.

22. Zhou S, Wang L, Panossian A, Anselmo D, Wu S, Venkatramani R. Refractory Kaposiform Hemangioendothelioma associated with the chromosomal translocation t(13;16)(q14;p13.3). Pediatr Dev Pathol. 2016;19(5):417-20.

23. Lim YH, Bacchiocchi A, Qiu J, Straub R, Bruckner A, Bercovitch L, et al. GNA14 somatic mutation causes congenital and sporadic vascular tumors by MAPK activation. Am J Hum Genet. 2016;99(2):443-50.

24. Bean GR, Joseph NM, Folpe AL, Horvai AE, Umetsu SE. RecurrentGNA14 mutations in anastomosing haemangiomas. Histopathology. 2018;73(2):354-7.

25. Ayturk UM, Couto JA, Hann S, Mulliken JB, Williams KL, Huang AY, et al. Somatic activating mutations in GNAQ and GNA11 are associated with congenital Hemangioma. Am J Hum Genet. 2016;98(6):1271.

26. Shirley MD, Tang H, Gallione CJ, Baugher JD, Frelin LP, Cohen B, et al. Sturge-weber syndrome and port-wine stains caused by somatic mutation in GNAQ. N Engl J Med. 2013:368(21):1971-9.

27. Couto JA, Huang L, Vivero MP, Kamitaki N, Maclellan RA, Mulliken JB, et al. Endothelial Cells from Capillary Malformations Are Enriched for Somatic GNAQ Mutations. Plast Reconstr Surg. 2016;137(1):77e-82e. 
28. Van Raamsdonk CD, Bezrookove V, Green G, Bauer J, Gaugler L, O'Brien JM et al. Frequent somatic mutations of GNAQ in uveal melanoma and blue naevi. Nature. 2009;457(7229):599-602.

29. Joseph NM, Brunt EM, Marginean C, Nalbantoglu I, Snover DC, Thung SN, et al. Frequent GNAQ and GNA14 mutations in hepatic small vessel neoplasm. The Am J Surg Pathol. 2018;42(9):1201-7.

30. Couto JA, Ayturk UM, Konczyk DJ, Goss JA, Huang AY, Hann S, et al. A somatic GNA11 mutation is associated with extremity capillary malformation and overgrowth. Angiogenesis. 2017;20(3):303-6.

31. Hutchings CJ, Koglin M, Olson WC, Marshall FH. Opportunities for therapeutic antibodies directed at G-protein-coupled receptors. Nat Rev Drug Discov. 2017;16(9):661.

32. Kimple AJ, Bosch DE, Giguere PM, Siderovski DP. Regulators of G-protein signaling and their Galpha substrates: promises and challenges in their use as drug discovery targets. Pharmacol Rev. 2011;63(3):728-49.

33. Greene AK, Goss JA. Vascular Anomalies. Plast Reconstr Surg. 2018;141(5): 709e-17e.

34. Dadras SS, Skrzypek A, Nguyen L, Shin JW, Schulz MM, Arbiser J, et al. Prox-1 promotes invasion of kaposiform hemangioendotheliomas. J Invest Dermatol. 2008;128(12):2798-806.

35. Glaser K, Dickie P, Dickie BH. Proliferative cells from Kaposiform Lymphangiomatosis lesions resemble mesenchyme stem cell-like Pericytes defective in vessel formation. J Pediatr Hematol Oncol. 2018;40(8):e495-504.

36. Flister MJ, Wilber A, Hall KL, Iwata C, Miyazono K, Nisato RE, et al. Inflammation induces lymphangiogenesis through up-regulation of VEGFR-3 mediated by NF-kappaB and Prox1. Blood. 2010;115(2):418-29.

37. Saito M, Gunji Y, Kashii Y, Odaka J, Yamauchi T, Kanai N, et al. Refractory kaposiform hemangioendothelioma that expressed vascular endothelial growth factor receptor (VEGFR)-2 and VEGFR-3: a case report. J Pediatr Hematol Oncol. 2009;31(3):194-7.

38. Folpe AL, Veikkola T, Valtola R, Weiss SW. Vascular endothelial growth factor receptor-3 (VEGFR-3): a marker of vascular tumors with presumed lymphatic differentiation, including Kaposi's sarcoma, kaposiform and Dabska-type hemangioendotheliomas, and a subset of angiosarcomas. Mod Pathol. 2000; 13(2):180-5

39. Karpanen T, Egeblad M, Karkkainen MJ, Kubo H, Yla-Herttuala S, Jaattela M, et al. Vascular endothelial growth factor $C$ promotes tumor lymphangiogenesis and intralymphatic tumor growth. Cancer Res. 2001; 61(5):1786-90

40. Varney ML, Singh RK. VEGF-C-VEGFR3/Flt4 axis regulates mammary tumor growth and metastasis in an autocrine manner. Am J Cancer Res. 2015;5(2): 616-28.

41. Lohela M, Bry M, Tammela T, Alitalo K. VEGFs and receptors involved in angiogenesis versus lymphangiogenesis. Curr Opin Cell Biol. 2009;21(2): 154-65.

42. Hsu M, Pan M, Hung W. Two birds, one stone: double hits on tumor growth and Lymphangiogenesis by targeting vascular endothelial growth factor receptor 3. Cells. 2019;8(3):270.

43. Varricchi G, Granata F, Loffredo S, Genovese A, Marone G. Angiogenesis and lymphangiogenesis in inflammatory skin disorders. J Am Acad Dermatol. 2015;73(1):144-53.

44. Le Cras TD, Mobberley-Schuman PS, Broering M, Fei L, Trenor CC, Adams DM. Angiopoietins as serum biomarkers for lymphatic anomalies. Angiogenesis. 2017;20(1):163-73.

45. Saharinen $P$, Eklund $L$, Alitalo K. Therapeutic targeting of the angiopoietinTIE pathway. Nat Rev Drug Discov. 2017;16(9):635-61.

46. Saharinen $P$, Eklund L, Miettinen J, Wirkkala R, Anisimov A, Winderlich M et al. Angiopoietins assemble distinct Tie2 signalling complexes in endothelial cell-cell and cell-matrix contacts. Nat Cell Biol. 2008;10(5):527-37.

47. Kim I, Kim HG, So JN, Kim JH, Kwak HJ, Koh GY. Angiopoietin-1 regulates endothelial cell survival through the phosphatidylinositol 3'-kinase/Akt signal transduction pathway. Circ Res. 2000;86(1):24-9.

48. Gruman A, Liang MG, Mulliken JB, Fishman SJ, Burrows PE, Kozakewich HPW, et al. Kaposiform hemangioendothelioma without Kasabach-Merritt phenomenon. J Am Acad Dermatol. 2005;52(4):616-22.

49. Arai E, Kuramochi A, Tsuchida T, Tsuneyoshi M, Kage M, Fukunaga M, et al. Usefulness of D2-40 immunohistochemistry for differentiation between kaposiform hemangioendothelioma and tufted angioma. J Cutan Pathol. 2006;33(7):492-7.

50. Debelenko LV, Perez-Atayde AR, Mulliken JB, Liang MG, Archibald TH, Kozakewich HP. D2-40 immunohistochemical analysis of pediatric vascular tumors reveals positivity in kaposiform hemangioendothelioma. Mod Pathol. 2005;18(11):1454-60.

51. Pollitt AY, Poulter NS, Gitz E, Navarro-Nunez L, Wang YJ, Hughes CE, et al. Syk and Src family kinases regulate C-type lectin receptor 2 (CLEC-2)mediated clustering of podoplanin and platelet adhesion to lymphatic endothelial cells. J Biol Chem. 2014;289(52):35695-710.

52. Florez-Vargas A, Vargas SO, Debelenko LV, Perez-Atayde AR, Archibald T, Kozakewich HP, et al. Comparative analysis of D2-40 and LYVE-1 immunostaining in lymphatic malformations. Lymphology. 2008;41(3): $103-10$.

53. Le Huu AR, Jokinen CH, Rubin BP, Mihm MC, Weiss SW, North PE, et al. Expression of prox1, lymphatic endothelial nuclear transcription factor, in Kaposiform hemangioendothelioma and tufted angioma. Am J Surg Pathol. 2010;34(11):1563-73

54. Ruggeri ZM, Orje JN, Habermann R, Federici AB, Reininger AJ. Activationindependent platelet adhesion and aggregation under elevated shear stress. Blood. 2006;108(6):1903-10.

55. Ikeda Y, Handa M, Kawano K, Kamata T, Murata M, Araki Y, et al. The role of von Willebrand factor and fibrinogen in platelet aggregation under varying shear stress. J Clin Invest. 1991;87(4):1234-40.

56. Di Vito C, Navone SE, Marfia G, Abdel HL, Mancuso ME, Pecci A, et al. Platelets from glioblastoma patients promote angiogenesis of tumor endothelial cells and exhibit increased VEGF content and release. Platelets. 2017;28(6):585-94

57. Wojtukiewicz MZ, Sierko E, Hempel D, Tucker SC, Honn KV. Platelets and cancer angiogenesis nexus. Cancer Metastasis Rev. 2017;36(2): 249-62.

58. Janowska-Wieczorek A, Wysoczynski M, Kijowski J, Marquez-Curtis L, Machalinski B, Ratajczak J, et al. Microvesicles derived from activated platelets induce metastasis and angiogenesis in lung cancer. Int J Cancer. 2005;113(5):752-60.

59. Verheul HM, Jorna AS, Hoekman K, Broxterman HJ, Gebbink MF, Pinedo HM. Vascular endothelial growth factor-stimulated endothelial cells promote adhesion and activation of platelets. Blood. 2000;96(13):4216-21.

60. Olsson AK, Cedervall J. The pro-inflammatory role of platelets in cancer. Platelets. 2018;29(6):569-73.

61. Caine GJ, Lip GY, Stonelake PS, Ryan P, Blann AD. Platelet activation, coagulation and angiogenesis in breast and prostate carcinoma. Thromb Haemost. 2004;92(1):185-90.

62. Chan S, Cassarino DS. Rapidly enlarging "bruise" on the Back of an infant. JAMA Dermatol. 2013;149(11):1337.

63. Zhang G, Gao Y, Liu X. Kaposiform haemangioendothelioma in a nine-yearold boy with Kasabach-Merritt phenomenon. Br J Haematol. 2017;179(1):9.

64. Rodriguez V, Lee A, Witman PM, Anderson PA. Kasabach-Merritt Phenomenon. J Pediatr Hematol Oncol. 2009;31(7):522-6.

65. Mulliken JB, Young AE. Vascular birthmarks: hemangiomas and malformations: WB Saunders company; 1988.

66. San Miguel FL, Spurbeck W, Budding C, Horton J. Kaposiform hemangioendothelioma: a rare cause of spontaneous hemothorax in infancy. Review of the literature. J Pediatr Surg. 2008;43(1):e37-41.

67. Iwami D, Shimaoka S, Mochizuki I, Sakuma T. Kaposiform hemangioendothelioma of the mediastinum in a 7-month-old boy: a case report. J Pediatr Surg. 2006;41(8):1486-8.

68. Duan L, Renzi S, Weidman D, Waespe N, Chami R, Manson D, et al. Sirolimus Treatment of an Infant With Intrathoracic Kaposiform Hemangioendothelioma Complicated by Life-threatening Pleural and Pericardial Effusions. J Pediatr Hematol Oncol. 2020;42(1):74-78

69. Oza VS, Mamlouk MD, Hess CP, Mathes EF, Frieden IJ. Role of Sirolimus in advanced Kaposiform Hemangioendothelioma. Pediatr Dermatol. 2016;33(2):e88-92

70. Ji Y, Yang K, Chen S, Peng S, Lu G, Liu X. Musculoskeletal complication in kaposiform hemangioendothelioma without Kasabach\&ndash;Merritt phenomenon: clinical characteristics and management. Cancer Manag Res. 2018;10:3325-31.

71. Keskindemirci G, Tugcu D, Aydogan G, Akcay A, Aktay AN, Er A, et al. Paravertebral and retroperitoneal vascular tumour presenting with Kasabach-Merritt phenomenon in childhood, Diagnosed with Magnetic Resonance Imaging. Case Rep Pediatr. 2015;2015:537530.

72. Zhu Y, Qiu G, Zhao H, Liang J, Shi X. Kaposiform hemangioendothelioma with adolescent thoracic scoliosis: a case report and review of literature. Eur Spine J. 2011;20(Suppl 2):S309-13. 
73. Ji Y, Chen S, Li L, Yang K, Xia C, Li L, et al. Kaposiform hemangioendothelioma without cutaneous involvement. J Cancer Res and Clin. 2018;144(12):2475-84.

74. Lindberg U, Svensson L, Hellmark T, Segelmark M, Shannon O. Increased platelet activation occurs in cystic fibrosis patients and correlates to clinical status. Thromb Res. 2018;162:32-7.

75. Zaldivar MM, Pauels K, von Hundelshausen P, Berres ML, Schmitz P, Bornemann J, et al. CXC chemokine ligand $4(\mathrm{CXC} / 4)$ is a platelet-derived mediator of experimental liver fibrosis. Hepatology. 2010;51(4):1345-53.

76. Schook CC, Mulliken JB, Fishman SJ, Alomari Al, Grant FD, Greene AK. Differential diagnosis of lower extremity enlargement in pediatric patients referred with a diagnosis of lymphedema. Plast Reconstr Surg. 2011;127(4): 1571-81.

77. Hammill A, Mobberley-Schuman P, Adams D. Lymphoedema is a potential sequela of kaposiform haemangioendothelioma. Br J Dermatol. 2016;175(4): 833-4.

78. Konczyk DJ, Goss JA, Maclellan RA, Greene AK. Association between extremity kaposiform hemangioendothelioma and lymphedema. Pediatr Dermatol. 2018;35(1):e92-3.

79. Kim DW, Chung JH, Ahn SH, Kwon T. Laryngeal kaposiform hemangioendothelioma: case report and literature review. Auris Nasus Larynx. 2010;37(2):258-62.

80. Wang C, Li Y, Xiang B, Li F, Chen S, Li L, et al. Successful Management of Pancreatic Kaposiform Hemangioendothelioma with Sirolimus. Pancreas. 2017:46(5):e39-41.

81. Leung M, Chao NS, Tang PM, Liu K, Chung KL. Pancreatic kaposiform hemangioendothelioma presenting with duodenal obstruction and kasabach-Merritt phenomenon: a neonate cured by whipple operation. European J Pediatr Surg Rep. 2014;2(1):7-9.

82. Gong $X$, Ying $H$, Zhang Z, Wang L, Li J, Ding A, et al. Ultrasonography and magnetic resonance imaging features of kaposiform hemangioendothelioma and tufted angioma. J Dermatol. 2019;46(10):835-42

83. Drolet BA, Trenor CC, Brandão LR, Chiu YE, Chun RH, Dasgupta R, et al. Consensus-derived practice standards plan for complicated Kaposiform Hemangioendothelioma. J Pediatr. 2013;163(1):285-91.

84. Hu P, Zhou Z. Clinical and imaging features of Kaposiform Hemangioendothelioma. Br J Radiol. 2018;91(1086):20170798.

85. Ryu YJ, Choi YH, Cheon J, Kim WS, Kim I, Park JE, et al. Imaging findings of Kaposiform Hemangioendothelioma in children. Eur J Radiol. 2017;86:198-205.

86. Tollefson MM, Frieden IJ. Early growth of infantile hemangiomas: what parents' photographs tell us. Pediatrics. 2012;130(2):e314-20.

87. Krowchuk DP, Frieden IJ, Mancini AJ, Darrow DH, Blei F, Greene AK, et al. Clinical practice guideline for the Management of Infantile Hemangiomas. Pediatrics. 2019;143(1):e20183475.

88. Léauté-Labrèze C, Harper Jl, Hoeger PH. Infantile haemangioma. Lancet. 2017;390(10089):85-94

89. Mulliken JB, Enjolras O. Congenital hemangiomas and infantile hemangioma: missing links. J Am Acad Dermatol. 2004;50(6):875-82.

90. Nasseri E, Piram M, McCuaig CC, Kokta V, Dubois J, Powell J. Partially involuting congenital hemangiomas: a report of 8 cases and review of the literature. J Am Acad Dermatol. 2014;70(1):75-9.

91. Knöpfel N, Wälchli R, Luchsinger I, Theiler M, Weibel L, Schwieger BA. Congenital hemangioma exhibiting postnatal growth. Pediatr Dermatol. 2019;36(4):548-9.

92. Baselga E, Cordisco MR, Garzon M, Lee MT, Alomar A, Blei F. Rapidly involuting congenital haemangioma associated with transient thrombocytopenia and coagulopathy: a case series. Br J Dermatol. 2008; 158(6):1363-70.

93. Dompmartin A, Acher A, Thibon P, Tourbach S, Hermans C, Deneys V, et al. Association of localized intravascular coagulopathy with venous malformations. Arch Dermatol. 2008;144(7):873-7.

94. Dompmartin A, Vikkula M, Boon LM. Venous malformation: update on aetiopathogenesis, diagnosis and management. Phlebology. 2010;25(5): 224-35.

95. Boland JM, Tazelaar HD, Colby TV, Leslie KO, Hartman TE, Yi ES. Diffuse pulmonary lymphatic disease presenting as interstitial lung disease in adulthood: report of 3 cases. Am J Surg Pathol. 2012;36(10):1548-54.

96. Croteau SE, Kozakewich HP, Perez-Atayde AR, Fishman SJ, Alomari Al, Chaudry G, et al. Kaposiform lymphangiomatosis: a distinct aggressive lymphatic anomaly. J Pediatr. 2014;164(2):383-8.
97. Safi F, Gupta A, Adams D, Anandan V, McCormack FX, Assaly R. Kaposiform lymphangiomatosis, a newly characterized vascular anomaly presenting with hemoptysis in an adult woman. Ann Am Thorac Soc. 2014;11(1):92-5.

98. Ji Y, Chen S, Peng S, Xia C, Li L. Kaposiform lymphangiomatosis and kaposiform hemangioendothelioma: similarities and differences. Orphanet J Rare Dis. 2019;14(1):165.

99. Kato H, Ozeki M, Fukao T, Matsuo M. MR imaging findings of vertebral involvement in Gorham-stout disease, generalized lymphatic anomaly, and kaposiform lymphangiomatosis. Jpn J Radiol. 2017;35(10):606-12.

100. Barclay SF, Inman KW, Luks VL, McIntyre JB, Al-Ibraheemi A, Church AJ, et al. A somatic activating NRAS variant associated with kaposiform lymphangiomatosis. Genet Med. 2019;21(7):1517-24.

101. Tower RL. Kaposiform haemangioendothelioma: new insights and old problems. Br J Dermatol. 2018;179(2):253-4.

102. Freixo C, Ferreira V, Martins J, Almeida R, Caldeira D, Rosa M, et al. Efficacy and safety of sirolimus in the treatment of vascular anomalies: a systematic review. J Vasc Surg. 2019. https://doi.org/10.1016/j.jvs.2019.06.217.

103. Haisley-Royster C, Enjolras O, Frieden IJ, Garzon M, Lee M, Oranje A, et al. Kasabach-Merritt phenomenon: a retrospective study of treatment with vincristine. J Pediatr Hematol Oncol. 2002;24(6):459-62.

104. Fahrtash F, McCahon E, Arbuckle S. Successful treatment of Kaposiform Hemangioendothelioma and tufted Angioma with vincristine. J Pediatr Hematol Oncol. 2010;32(6):506-10.

105. Wang Z, Li K, Yao W, Dong K, Xiao X, Zheng S. Steroid-resistant kaposiform hemangioendothelioma: a retrospective study of 37 patients treated with vincristine and long-term follow-up. Pediatr Blood Cancer. 2015;62(4):577-80.

106. Liu X, Li J, Qu X, Yan W, Zhang L, Zhang S, et al. Clinical outcomes for systemic corticosteroids versus vincristine in treating Kaposiform Hemangioendothelioma and tufted Angioma. Medicine. 2016;95(20):e3431.

107. Tlougan BE, Lee MT, Drolet BA, Frieden IJ, Adams DM, Garzon MC. Medical Management of Tumors Associated with Kasabach-Merritt Phenomenon. J Pediatr Hematol Oncol. 2013;35(8):618-22.

108. Peng S, Yang K, Xu Z, Chen S, Ji Y. Vincristine and sirolimus in the treatment of kaposiform haemangioendothelioma. J Paediatr Child H. 2019;55(9):1119-24.

109. Tan X, Zhang J, Zhou S, Liu Z, Zhang T, Xia J. Successful management of steroid-resistant vascular tumors associated with the Kasabach-Merritt phenomenon using sirolimus. J Dermatol. 2018;45(5):580-3.

110. Kai L, Wang Z, Yao W, Dong K, Xiao X. Sirolimus, a promising treatment for refractory Kaposiform hemangioendothelioma. J Cancer Res Clin. 2014; 140(3):471-6

111. Lopez V, Marti N, Pereda C, Martin JM, Ramon D, Mayordomo E, et al. Successful management of Kaposiform hemangioendothelioma with Kasabach-Merritt phenomenon using vincristine and ticlopidine. Pediatr Dermatol. 2009:26(3):365-6.

112. Liu XH, Li JY, Qu XH, Yan WL, Zhang L, Yang C, et al. Treatment of kaposiform hemangioendothelioma and tufted angioma. Int J Cancer. 2016; 139(7):1658-66

113. George ME, Sharma V, Jacobson J, Simon S, Nopper AJ. Adverse effects of systemic Glucocorticosteroid therapy in infants with Hemangiomas. Arch Dermatol. 2004;140(8):963-9.

114. Ji Y, Chen S, Xiang B, Li K, Xu Z, Yao W, et al. Sirolimus for the treatment of progressive kaposiform hemangioendothelioma: a multicenter retrospective study. Int J Cancer. 2017;141(4):848-55.

115. Boccara O, Puzenat E, Proust S, Leblanc T, Lasne D, Hadj-Rabia S, et al. The effects of sirolimus on Kasabach-Merritt phenomenon coagulopathy. British J Dermatol. 2018;178(2):e114-6.

116. Zhang G, Chen H, Gao Y, Liu Y, Wang J, Liu XY. Sirolimus for treatment of Kaposiform haemangioendothelioma with Kasabach-Merritt phenomenon: a retrospective cohort study. Brit J Dermatol. 2018;178(5):1213-4.

117. Triana P, Dore M, Cerezo V, Cervantes $M$, Sánchez A, Ferrero M, et al. Sirolimus in the treatment of vascular anomalies. Eur J Pediatr Surg. 2017; 27(01):086-90.

118. Tasani M, Ancliff P, Glover M. Sirolimus therapy for children with problematic kaposiform haemangioendothelioma and tufted angioma. Brit J Dermatol. 2017;177(6):e344-6.

119. Wang H, Duan Y, Gao Y, Guo X. Sirolimus for vincristine-resistant Kasabach-Merritt phenomenon: report of eight patients. Pediatr Dermatol. 2017:34(3):261-5.

120. Adams DM, Trenor CC, Hammill AM, Vinks AA, Patel MN, Chaudry G, et al. Efficacy and safety of Sirolimus in the treatment of complicated vascular anomalies. Pediatrics. 2016;137(2):e20153257. 
121. Nadal M, Giraudeau B, Tavernier E, Jonville-Bera A, Lorette G, Maruani A. Efficacy and safety of mammalian target of Rapamycin inhibitors in vascular anomalies: a systematic review. Acta Dermato Venereologica. 2016;96(4): 448-52.

122. Wang Z, Li K, Dong K, Xiao X, Zheng S. Successful treatment of KasabachMerritt phenomenon arising from Kaposiform Hemangioendothelioma by Sirolimus. J Pediatr Hematol Oncol. 2015;37(1):72-3.

123. Lackner H, Karastaneva A, Schwinger W, Benesch M, Sovinz P, Seidel M, et al. Sirolimus for the treatment of children with various complicated vascular anomalies. Eur J Pediatr. 2015;174(12):1579-84.

124. Blatt J, Stavas J, Moats-Staats B, Woosley J, Morrell DS. Treatment of childhood kaposiform hemangioendothelioma with sirolimus. Pediatr Blood Cancer. 2010;55(7):1396-8.

125. Russell TB, Rinker EK, Dillingham CS, Givner LB, McLean TW. Pneumocystis Jirovecii pneumonia during Sirolimus therapy for Kaposiform Hemangioendothelioma. Pediatrics. 2018;141(Suppl 5):S421.

126. Ying H, Qiao C, Yang X, Lin X. A case report of 2 Sirolimus-related deaths among infants with Kaposiform Hemangioendotheliomas. Pediatrics. 2018; 141(Suppl 5):S425-9.

127. Mariani LG, Schmitt IR, Garcia CD, Kiszewski AE. Low dose sirolimus treatment for refractory tufted angioma and congenital kaposiform hemangioendothelioma, both with Kasabach-Merritt phenomenon. Pediatr Blood Cancer. 2019;66(8):e27810.

128. Zhu J, Wu J, Frizell E, Liu SL, Bashey R, Rubin R, et al. Rapamycin inhibits hepatic stellate cell proliferation in vitro and limits fibrogenesis in an in vivo model of liver fibrosis. Gastroenterology. 1999;117(5):1198-204.

129. Wu MJ, Wen MC, Chiu YT, Chiou YY, Shu KH, Tang MJ. Rapamycin attenuates unilateral ureteral obstruction-induced renal fibrosis. Kidney Int. 2006;69(11):2029-36.

130. Burleigh A, Kanigsberg N, Lam JM. Topical rapamycin (sirolimus) for the treatment of uncomplicated tufted angiomas in two children and review of the literature. Pediatr Dermatol. 2018;35(5):e286-90

131. Zhang X, Yang K, Chen S, Ji Y. Tacrolimus ointment for the treatment of superficial kaposiform hemangioendothelioma and tufted angioma. J Dermatol. 2019:46(10):898-901

132. Paller AS, Eichenfield LF, Kirsner RS, Shull T, Jaracz E, Simpson EL. Three times weekly tacrolimus ointment reduces relapse in stabilized atopic dermatitis: a new paradigm for use. Pediatrics. 2008;122(6):e1210-8.

133. Moimeaux V, Taieb A, Legrain V, Meraud JP, Jimenez M, Choussat A, et al. Aspirin-ticlopidin in Kasabach-Merritt syndrome. Lancet. 1992;340(8810):55.

134. Wu HW, Wang X, Zhang L, Zhao HG, Wang YA, Su LX, et al. Interferon-alpha therapy for refractory kaposiform hemangioendothelioma: a single-center experience. Sci Rep. 2016;6:36261.

135. Hermans DJ, van Beynum IM, van der Vijver RJ, Kool $L$, de Blaauw I, van der Vleuten CJ. Kaposiform hemangioendothelioma with Kasabach-Merritt syndrome: a new indication for propranolol treatment. J Pediatr Hematol Oncol. 2011;33(4)::171-3.

136. Chiu YE, Drolet BA, Blei F, Carcao M, Fangusaro J, Kelly ME, et al. Variable response to propranolol treatment of kaposiform hemangioendothelioma, tufted angioma, and Kasabach-Merritt phenomenon. Pediatr Blood Cancer. 2012;59(5):934-8.

137. Filippi L, Tamburini A, Berti E, Perrone A, Defilippi C, Favre C, et al. Successful propranolol treatment of a Kaposiform Hemangioendothelioma apparently resistant to propranolol. Pediatr Blood Cancer. 2016;63(7):1290-2

138. Barlow CF, Priebe CJ, Mulliken JB, Barnes PD, Mac DD, Folkman J, et al. Spastic diplegia as a complication of interferon Alfa-2a treatment of hemangiomas of infancy. J Pediatr. 1998;132(3 Pt 1):527-30.

139. Wang P, Zhou W, Tao L, Zhao N, Chen XW. Clinical analysis of KasabachMerritt syndrome in 17 neonates. BMC Pediatr. 2014:14:146.

\section{Publisher's Note}

Springer Nature remains neutral with regard to jurisdictional claims in published maps and institutional affiliations.

Ready to submit your research? Choose BMC and benefit from:

- fast, convenient online submission

- thorough peer review by experienced researchers in your field

- rapid publication on acceptance

- support for research data, including large and complex data types

- gold Open Access which fosters wider collaboration and increased citations

- maximum visibility for your research: over $100 \mathrm{M}$ website views per year

At BMC, research is always in progress.

Learn more biomedcentral.com/submissions 